\title{
Retraction: Historical facts of screening and diagnosing diabetes in pregnancy
}

\author{
Carlos Antonio Negrato ${ }^{1 *}$ and Marilia Brito Gomes ${ }^{2}$
}

\section{Retraction}

This article [1] has been retracted by the Editor due to extensive overlap in text with a number of previous publications, most notably those by Mestman, Lowe et al. and Agarwal [2-4].

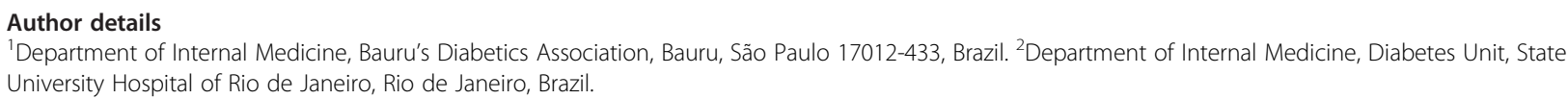

Received: 20 May 2014 Accepted: 20 May 2014

Published: 27 May 2014

\section{References}

1. Negrato C, Gomes M: Historical facts of screening and diagnosing diabetes in pregnancy. Diabetol Metabol Syndr 2013, 5:22.

2. Mestman JH: Historical notes on diabetes in pregnancy. Endocrinologist 2002, 12:224-242.

3. Lynn PL, et al: Hyperglycaemia and Adverse Pregnancy Outcomes (HAPO) Study: An Overview. In Gestational Diabetes Before and After Pregnancy. Chapter 2nd edition. Edited by Kim C, Ferrara A. London: Springer; 2011:17-34.

4. Mukesh A: Evolution of Screening and Diagnostic Criteria for GDM Worldwide. In Gestational Diabetes Before and After Pregnancy. Chapter 3rd edition. Edited by Kim C, Ferrara A. London: Springer; 2011:35-49.

\section{doi:10.1186/1758-5996-6-59}

Cite this article as: Negrato and Gomes: Retraction: Historical facts of screening and diagnosing diabetes in pregnancy. Diabetology \& Metabolic Syndrome 2014 6:59.

\footnotetext{
* Correspondence: carlosnegrato@uol.com.br

'Department of Internal Medicine, Bauru's Diabetics Association, Bauru, São Paulo 17012-433, Brazil

\section{Submit your next manuscript to BioMed Central} and take full advantage of:

- Convenient online submission

- Thorough peer review

- No space constraints or color figure charges

- Immediate publication on acceptance

- Inclusion in PubMed, CAS, Scopus and Google Scholar

- Research which is freely available for redistribution 